УДК 65.51

\title{
МОДЕЛЬ ВПРОВАДЖЕННЯ ПРОЕКТУ \\ РЕІНЖИНІРИНГУ БІЗНЕС-ПРОЦЕСІВ \\ У ТРАНСПОРТНО-ЛОГІСТИЧНІЙ ГАЛУЗІ
}

\begin{abstract}
MODEL OF IMPLEMENTATION OF THE PROJECT OF REENGINEERING OF BUSINESS PROCESSES IN THE TRANSPORT AND LOGISTICS INDUSTRY
\end{abstract}

\author{
Шилова Тамара Олександрівна \\ аспірантка, \\ Одеський національний економічний університет \\ ORCID: https://orcid.org/0000-0002-0255-9700
}

\author{
Shilova Tamara \\ Odessa National Economics University
}

\begin{abstract}
Упровадження науково обґрунтованої моделі реінжинірингу бізнес-процесів на підприємстві є передумовою якісного та кількісного прогресу не лише показників ефективності за всіма видами діяльності, але й підвищення інвестиційної привабливості фрірми завдяки зростанню оціночної вартості. У статті висвітлено теоретико-методичні засади формування та застосування моделі впровадження проекту реінжинірингу бізнес-процесів на підприємствах транспортно-логістичної галузі. Теоретичною базою дослідження $є$ наукові положення та висновки зарубіжних і вітчизняних учених щодо реінжинірингу бізнес-процесів. Проаналізовано раніше запропоновані алгоритми реінжинірингу бізнес-процесів, розглянуто методологічний базис цих розробок і вказано на наявні недоліки. Виявлені тенденції, принципи, методи та технології реінжинірингу та його реалізації були отримані шляхом компаративного аналізу попередніх напрацювань щодо алгоритмів упровадження реінжинірингу в бізнес-модель підприємства. Обґрунтовано важливість урахування міжнародних стандартів (зокрема, ISO 9001) при запровадженні моделі реінжинірингу на підприємствах, операційна діяльність яких пов'язана із взаємодією з іноземними контрагентами та регуляторами. Представлено власну інноваційну модель впровадження проекту реінжинірингу бізнес-процесів, детально описано алгоритм ії функціонування. Ця модель складається з дев'яти етапів (підготовка, розробка моделі компанії, вибір та аналіз бізнес-процесів, стратегічне планування та розвиток інноваційної ідеї, затвердження інноваційної ідеї, впровадження нової моделі, контроль, і постійне вдосконалення). Наголошено на необхідності ефективного поєднання системного та процесного підходу при впровадженні вказаної моделі. Підкреслено прикладну цінність розробки, що полягає як у задоволенні вимог щодо успішного реінжинірингу та покращенні взаємодії підрозділів, так і в доцільному розподілі ресурсів і відповідальності на кожному з етапів здійснення реінжинірингу.

Ключові слова: бізнес-процес, вартість підприємства, реінжиніринг, транспортно-логістична галузь, ISO 9001.
\end{abstract}

Внедрение научно обоснованной модели реинжиниринга бизнес-процессов на предприятии является предпосылкой качественного и количественного прогресса не только показателей эффрективности по всем видам деятельности, но и повышение инвестиционной привлекательности фрирмы благодаря росту оценочной стоимости. В статье освещены теоретико-методические основы формирования и применения модели внедрения проекта реинжиниринга бизнес-процессов на предприятиях транспортно-логистической отрасли. Теоретической базой исследования являются научные положения и выводы зарубежных и отечественных ученых по реинжинирингу бизнес-процессов. Проанализированы ранее предложенные алгоритмы реинжиниринга бизнес-процессов, рассмотрены методологический базис этих разработок и имеющиеся недостатки. Выявленные тенденции, принципы, методы и технологии реинжиниринга и его реализации были получены путем сравнительного анализа предыдущих наработок по алгоритмам внедрения реинжиниринга в бизнесмодель предприятия. Обоснована важность учета международных стандартов (в частности, ISO 9001) при введении модели реинжиниринга на предприятиях, операционная деятельность которых связана с взаимодействием с иностранными контрагентами и регуляторами. Представлена собственная инновационная модель внедрения проекта реинжиниринга бизнес-процессов, подробно описан алгоритм ее функционирования. Эта модель состоит из девяти этапов (подготовка, разработка модели компании, выбор и анализ 
бизнес-процессов, стратегическое планирование и развитие инновационной идеи, утверждения инновационной идеи, внедрение новой модели, контроль и постоянное совершенствование). Отмечена необходимость эфрфективного сочетания системного и процессного подхода при внедрении указанной модели. Подчеркнута прикладная ценность разработки, заключенная как в удовлетворении требований относительно успешного реинжиниринга и улучшении взаимодействия подразделений, так и в целесообразном распределении ресурсов и ответственности на каждом этапе осуществления реинжиниринга.

Ключевые слова: бизнес-процесс, стоимость предприятия, реинжиниринг, транспортно-логистическая отрасль, ISO 9001.

The introduction of a scientifically sound model of business process reengineering at the enterprise is a prerequisite for qualitative and quantitative progress not only of efficiency indicators for all activities, but also increase the investment attractiveness of the firm due to the growth of appraised value. The article highlights the theoretical and methodological principles of formation and application of the implementation model of the business process reengineering project at the enterprises of the transport and logistics industry. The theoretical basis of the study is the scientific provisions and conclusions of foreign and domestic scientists on business process reengineering. The previously proposed algorithms for business process reengineering are analyzed, the methodological basis of these developments is considered and the existing shortcomings are pointed out. The identified trends, principles, methods and technologies of reengineering and its implementation were obtained through a comparative analysis of previous developments on the algorithms for implementing reengineering in the business model of the enterprise. The importance of taking into account of international standards (in particular, ISO 9001) in the implementation of the reengineering model in enterprises, whose operational activities are related to interaction with foreign counterparties and regulators is substantiated. The own innovative model of implementation of the business process reengineering project is presented, the algorithm of its functioning is described in detail. This model consists of nine stages (preparation, development of a company model, selection and analysis of business processes, strategic planning and development of an innovative idea, approval of an innovative idea, implementation of a new model, control, and continuous improvement). The need for an effective combination of system and process approach in the implementation of this model is emphasized. The applied value of the development is emphasized, which consists both in meeting the requirements for successful reengineering and improving the interaction of departments, and in the appropriate allocation of resources and responsibilities at each stage of reengineering.

Keywords: business process, enterprise cost, reengineering, transport and logistics industry, ISO 9001.

Постановка проблеми. Модернізація технологічної бази галузі сучасними та перспективними технологіями, розробка інноваційних продуктів, підвищення конкурентоспроможності підприємств транспортно-логістичної сорери в цілому та перехід на інноваційну модель економічного розвитку мають важливе значення в рамках модернізації національної економіки на засадах Industry 4.0.

Транспортні та логістичні технології впродовж останньої декади зазнали значних перетворень. IT-технології широко використовуються в управлінських цілях, але багато компаній все ще покладаються на старі та традиційні принципи управління, як це зазвичай робилося. Внаслідок цього, інноваційні управлінські рішення мають повсюдно впроваджуватися, оскільки інновації в управлінні набагато дешевші, ніж у виробничих технологіях. Окрім того, в короткостроковій перспективі інновації в управлінні матимуть велике значення для підвищення конкурентоспроможності на макроекономічному рівні. Безпосередній пошук інноваційної продукції в цих умовах замінюється управлінськими інноваціями, і це має бути основним напрямком стратегічних перетворень для будь-якого підприємства.
Теоретичною базою дослідження стали наукові положення та висновки, викладені в працях зарубіжних учених у галузі реінжинірингу бізнес-процесів. Реінжиніринг бізнес-процесів - одна 3 інноваційних управлінських технологій. Дослідження, на нашу думку, стає більш актуальним, оскільки в наш час інноваційний розвиток у транспортно-логістичній сорері стикається з фундаментальними проблемами.

Аналіз останніх досліджень і публікацій. Реінжиніринг, як одне 3 управлінських нововведень, набирає популярності, оскільки змінює спосіб впровадження бізнес-процесів, роблячи їх більш ефективними, що призводить, таким чином, до значного скорочення витрат, кращої виробничої спроможності, поліпшення якості, зниження частки рекламацій, втрат або браку, скорочення зайнятого персоналу (за рахунок автоматизації) та зростанні рівня задоволеності споживачів. У той же час його реалізація пов'язана з різноманітними проблемами, які можуть спричинити збої, про що свідчить світовий досвід та дослідження [1; 3; 5].

Все вищезазначене було актуальним для вибору об'єкту дослідження - реінжинірингу бізнес-процесів. 
Формулювання цілей статті (постановка завдання). Метою дослідження є обґрунтування методології реінжинірингу, який розглядається як інновація в процесному та системний підходах.

Виділення невирішених раніше частин загальної проблеми. У статті представлені результати фрундаментальних досліджень значущості адміністративних інновацій у транспортно-логістичній галузі. У цьому дослідженні використано системний підхід, що реалізує огляд підприємства як складної ієрархічної системи, а також процесного підходу до управління. Діалектичний метод дозволив здійснити розуміння специоріки сучасних організацій шляхом інноваційного розвитку та управління.

Виклад основного матеріалу дослідження. Революційні процеси підвищення ефрективності та продуктивності, автоматизації та оптимізації управління засновані на реінжинірингу бізнес-процесів, що дозволяє скоротити виробничі витрати, підвищити есрективність застосовуваних машин та обладнання, поліпшити якість продукції та зменшити кількість продукції, яка не відповідає конкретним вимогам, сприяють підвищенню рівня задоволеності споживачів та конкурентоспроможності підприємства в цілому. Незважаючи на низку перелічених вище переваг, світова практика демонструє, що цей метод, що передбачає сувору перестановку бізнесу, також має деякі недоліки.

Недостатня увага до реінжинірингу може бути причиною використання неефективних методів у реалізації алгоритмів цих заходів. Незважаючи на те, що доступні різні моделі впровадження реінжинірингу, на основі їх аналізу було зроблено висновок, що вони мають ряд недоліків, включаючи відсутність повного контролю за виконанням кожної фази, відсутність взаємозв'язку між результатами першої та кінцевої фраз реінжинірингу, використання більш загальних принципів цього процесу, відсутність конкретного плану робіт та призначення співробітників, відповідальних за їх виконання, а також відсутність методів та можливих засобів реінжинірингу на всіх його етапах, що сприяло б більш есрективному та результативному досягненню конкретних завдань і цілей. Вищевказані недоліки можна повністю або частково усунути, якщо реінжиніринг розглядати 3 точки зору технологічного підходу, тобто реалізовувати як набір взаємозалежних підпроцесів (фраз).
Для виявлення основних тенденцій, принципів, методів та технологій реінжинірингу та їх реалізації було порівняно деякі алгоритми $[1 ; 3 ; 4 ; 6]$, на основі отриманих результатів зроблені висновки нижче.

Якщо розглядати як фрази життєвого циклу продукту, проект реінжинірингу, як і будь-який інший проект, має початкову (попередній проект) фразу, фразу розробки, впровадження та завершення. Усі вивчені методики реінжинірингу подібні в цьому аспекті $[1 ; 3 ; 4 ; 7]$. Більшість аналізованих алгоритмів складається 3 чотирьох основних етапів: підготовка, аналіз поточної ситуації в компанії, реалізація реінжинірингу, впровадження нової бізнес-моделі; всі вони називаються по-різному, хоча зміст схожий.

Недоліки наявних алгоритмів включають відсутність контролю за реалізацією реінжинірингу бізнес-процесів і відсутність стратегічного планування, а також ефективність вжитих заходів не може бути оцінена. Крім того, автори звернулися не до всіх фраз взаємозв'язку; сорери реінжинірингу підпроцесів також не визначаються. Деякі заходи перераховані лише на кожному етапі, а технології їх виконання надаються без опису методів та засобів досягнення цілей. Агенти та учасники проекту розподіляються, хоча їх конкретні обов'язки в рамках проекту реінжинірингу не вказані. Не відбувається постійного вдосконалення бізнес-процесів. Більше того, деякі алгоритми не систематизовані; всі їх фрази точно не визначені, а міри не логічні. Також недоступні принципи, на які заходи реінжинірингу бізнес-процесів слід покладатися.

Отже, всі вищезазначені недоліки вказують на той фракт, що не існує належного алгоритму, який можна використовувати з метою реінжинірингу в будь-якій компанії; як наслідок, це впливає на якість, ефективність та результативність реінжинірингу бізнес-процесів, що призводить іноді до збоїв у впровадженні та значних фрінансово-економічних збитків компанії. Більшість сучасних компаній організовані фрункціонально, тобто вони мають лінійно-фрункціональну або фрункціональну організацію управління.

Підрозділи в таких організаціях залежать від їх фрункцій, але їхні стосунки з іншими підрозділами не визначені. Керівництво враховує підпорядкування підрозділів та персоналу. Ця фрорма організаційної структури не реагує швидко на суворі вимоги сучасного ринку.

Перш за все, це спричинено відсутністю відносин між підрозділами компанії та її стратегічними цілями, тому фрорма управління компанією в рамках процесуального підходу 
має регулюватися міжнародним стандартом ISO 9001. Це робить терміновим використання управління процесами та планування організаційних перетворень на рівні транспортно-логістичних комплексів та корпорацій, реалізованих на основі методів та принципів реінжинірингу. Організацію в даному випадку слід розглядати як відкриту систему, як комплекс взаємопов'язаних елементів, таких як персонал, структура, цілі та технології, які орієнтовані на швидке реагування на виклики, що виникають як у компанії, так і поза нею (зовнішнє середовище).

Підсумовуючи все вищезазначене, необхідно систематизувати ці заходи, розглядаючи реінжиніринг як процес, який складається 3 декількох фраз, спрямованих на зменшення можливих збоїв при впровадженні.

Для підвищення ефективності діяльності підприємств та корпорацій різних галузей вітчизняної та світової економіки пропонується алгоритм реалізації реінжинірингу бізнес-процесів, який спирається на теоретичні основи реінжинірингу бізнес-процесів та міжнародний стандарт ISO 9000.

Розроблений алгоритм може бути використаний у таких галузях економічної діяльності: планування, розробка та випробування нових товарів, закупівлі, логістика, маркетингові дослідження, продажі, управління відносинами із замовниками та постачальниками, виробничі процеси тощо.

Модель реалізації реінжинірингу наведена на рисунку 1.

Ця модель складається 3 дев'яти етапів: підготовка, розробка моделі компанії, вибір та аналіз бізнес-процесів, стратегічне планування та розвиток нового бізнесу (інноваційна ідея), затвердження інноваційної ідеї, впровадження нової моделі, контроль, і постійне вдосконалення. Більше того, ця модель враховує умови та принципи реалізації реінжинірингу, а також схему їі фраз із визначеною послідовністю дій.

При розробці розглянутої моделі план робіт був складений для кожної фрази як діаграма Гранта. План-графік може бути заданий та скоригований для різних підприємств, залежно від виду виробництва, галузі, економічної діяльності та цілей реінжинірингу.

Крім того, вхідні та вихідні дані визначались для кожної фрази з урахуванням цілей та цілей підпроцесу; що дає змогу побачити взаємозалежність фраз, оскільки вони відображаються як підпроцеси, де кожен наступний вихід є входом для іншої фрази.
Початковий внесок в реалізацію реінжинірингу - це розроблений стандарт організації в галузі управління проектами та регламенти впровадження проектів поетапно, він допомагає визначити відповідальність керівника проекту, керівників функціональних підрозділів, їх права та обов'язки, таким чином багато конфрліктів можна уникнути. Поряд зі стандартом у галузі управління проектами повинна бути сорормована система мотивації. Аналіз наявних теорій мотивації показав, що двофракторна теорія мотивації Герцберга $€$ найеорективнішою, вона дозволяє заохочувати працівників до дій у рамках їх профресійної діяльності за допомогою обох мотиваційних фракторів, які важливіші для їх мотивації та роботи умови, які навряд чи впливають на задоволення, але відмовляються від нього, якщо відсутні.

Розроблена модель реінжинірингу бізнеспроцесів також передбачає певні методи та засоби, які надалі здійснюють певний етап; вони включають діаграму Гранта, SWOTаналіз та модель Портера для визначення власної конкурентоспроможності. Для реалізації кожної фрази потрібні агенти та учасники: керівник - топ-менеджер, який схвалює проект реінжинірингу та мотивує; організаційний комітет - орган, що складається 3 керівників, які розробляють загальну стратегію реінжинірингу та контролюють її виконання; менеджер процесів - особа, відповідальна за бізнес-процеси та їх реінжиніринг; команда, що здійснює реінжиніринг - група людей, яка проводить діагностику наявного процесу, його перебудову та запровадження нових правил; консультант - учасник, який відповідально та вмотивовано займається розробкою методів та інструментів реінжинірингу.

Окрім вищезазначених характеристик розробленої моделі, суттєве значення мають принципи, які впливають на ключові фрактори успіху впровадження реінжинірингу. У міжнародних стандартах ISO 9000 зазначено, що принципи успішного, ефективного та результативного реінжинірингу включають: стратегічне управління; прийняття рішень, заснованих на фрактах; процесний підхід; системний підхід; орієнтація на споживача; залучення персоналу, керівництво менеджерами та прагнення до успіху.

Розроблена модель дозволяє задовольнити певні умови успішного реінжинірингу, такі як узгодження цілей проекту зі стратегічними цілями компанії, мотивація впровадження нової бізнес-моделі, ефективний та повний контроль змін, технологічне та мето- 


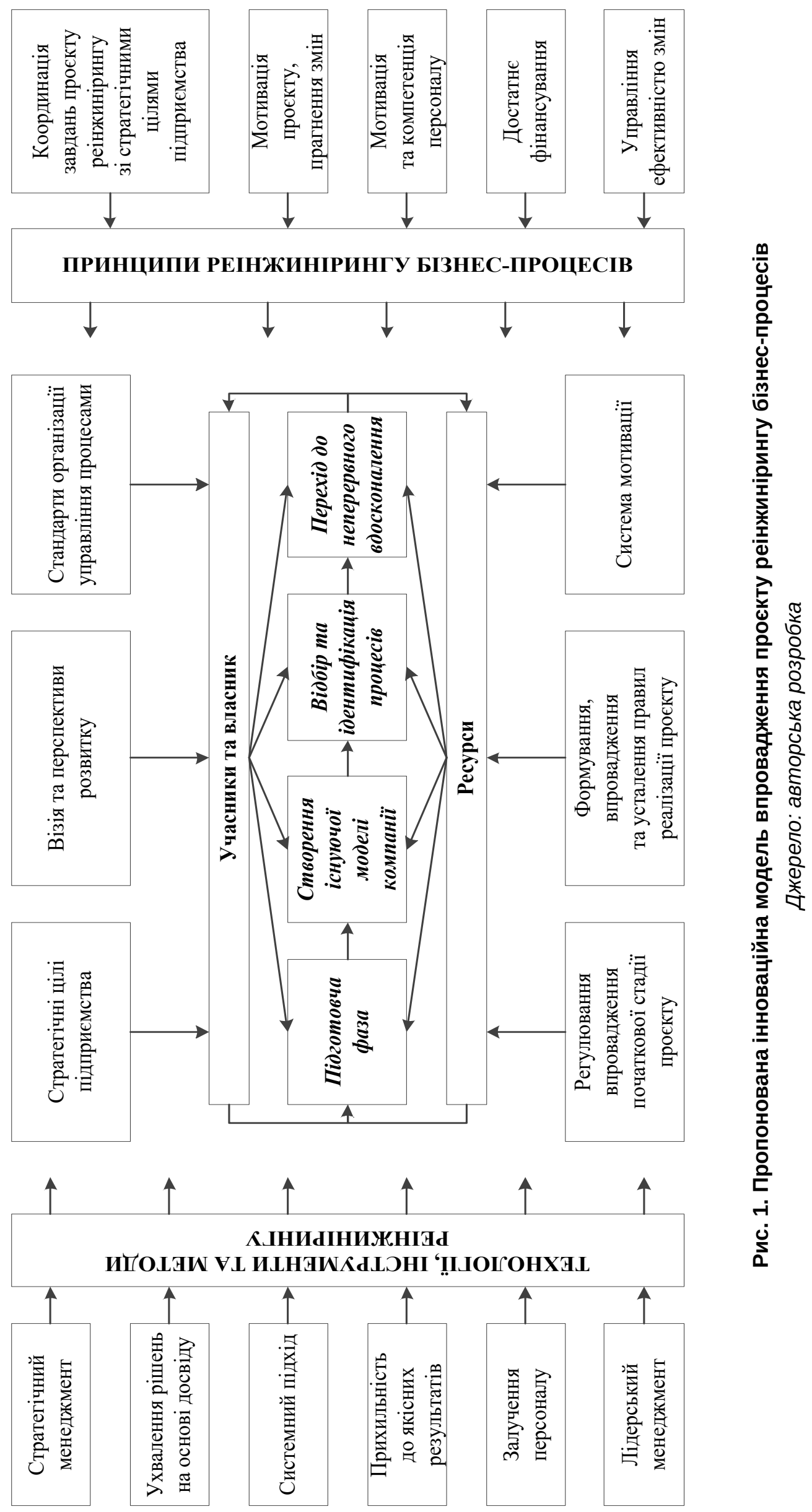


дичне забезпечення, вимоги внутрішнє та зовнішнє середовище, достатність забезпечених ресурсів для проекту реінжинірингу бізнес-процесів, а також визначення всіх фраз та взаємозалежність їх реалізації. Крім того, розглянутий підхід допомагає розподілити основні ресурси, методи та засоби, необхідні для реалізації етапу, його принципів та технологій.

Висновки. Запропонована процес-орієнтована модель алгоритму реінжинірингу $\epsilon$ ідеєю стратегічного інноваційного управління розвитком компанії та включає системний і процесний підходи, що формують нове поняття управління компанією в довгостроко- вій перспективі. Такий підхід дає можливість покращити взаємодію підрозділів, підвищити ефективність та ефрективність запроваджених заходів завдяки логічним наслідкам дій, суворому зверненню та розподілу відповідальності на кожному етапі.

Робота має певне практичне значення, тобто розробка моделі реінжинірингу бізнес-процесів допомагає задовольнити певні вимоги успішного реінжинірингу та покращити взаємодію підрозділів. Крім того, це підвищує ефективність введених заходів завдяки логічній послідовності дій та суворому розподілу ресурсів та відповідальності на кожному етапі.

\section{СПИСОК ВИКОРИСТАНИХ ДЖЕРЕЛ:}

1. Liu D.Z., Liu M., Zhong P.S. (2004). Method of product development process analysis and reengineering for concurrent engineering, Advances in Materials Manufacturing Science and Technology. China, Jinan. Vol. 471-472. P. 770-774.

2. Datsyk A.A., Grudina S.I., Avdonina S.G., Podgornaya A.I. (2016). Topical Issues of Influence of "Contraction Reengineering" on Structure of Business Management. Academy of Strategic Management Journal. Vol. 15. Special Issue 1. P. 67-82.

3. Verboncu I., Fucec A.A., Serban A.I., Rusu M. (2016). The impact of knowledge-based organizations on managerial reengineering. Proceedings of the 27th International Business Information Management Association Conference - Innovation Management and Education Excellence Vision 2020: From Regional Development Sustainability to Global Economic Growth, IBIMA. P. 753-764.

4. Lal Bhaskar H. (2016). A critical analysis of information technology and business process reengineering. International Journal of Productivity and Quality Management. Vol. 19. Issue 1. P. 98-115.

5. Grant D. (2016). Business analysis techniques in business reengineering. Business Process Management Journal. Vol. 22. Issue 1. P. 75-88.

6. Лизанець А.Г., Роман С.А. Реінжиніринг бізнес-процесів як метод вдосконалення ведення бізнесу. Науковий вісник Мукачівського державного університету. Серія : Економіка. 2018. Вип. 2. С. 54-59.

7. Чухрай Н.І., Матвій С.І. Реінжиніринг бізнес-процесів у централізації управління промисловим підприємством. Маркетинг і менеджмент інновацій. 2015. № 3. С. 172-181.

\section{REFERENCES:}

1. Liu D.Z., Liu M., Zhong P.S. (2004). Method of product development process analysis and reengineering for concurrent engineering. Advances in Materials Manufacturing Science and Technology. China, Jinan. Vol. 471-472, pp. 770-774.

2. Datsyk A.A., Grudina S.I., Avdonina S.G., Podgornaya A.I. (2016). Topical Issues of Influence of "Contraction Reengineering" on Structure of Business Management, Academy of Strategic Management Journal, vol. 15, special issue 1, p. 67-82.

3. Verboncu I., Fucec A.A., Serban A.I., Rusu M. (2016). The impact of knowledge-based organizations on managerial reengineering. Proceedings of the 27th International Business Information Management Association Conference - Innovation Management and Education Excellence Vision 2020: From Regional Development Sustainability to Global Economic Growth, IBIMA, pp. 753-764.

4. Lal Bhaskar H. (2016). A critical analysis of information technology and business process reengineering, International Journal of Productivity and Quality Management, vol. 19, issue 1, pp. 98-115.

5. Grant D. (2016). Business analysis techniques in business reengineering. Business Process Management Journal, vol. 22, issue 1, pp. 75-88.

6. Lyzanets A.H., Roman S.A. (2018). Reinzhynirynh biznes-protsesiv yak metod vdoskonalennia vedennia biznesu. Naukovyi visnyk Mukachivskoho derzhavnoho universytetu. Seriia: Ekonomika, vol. 2, pp. 54-59.

7. Chukhrai N.I., Matvii S.I. (2015). Reinzhynirynh biznes-protsesiv u tsentralizatsii upravlinnia promyslovym pidpryiemstvom. Marketynh i menedzhment innovatsii, no. 3, pp. 172-181. 